\title{
POLITICAL BROKER AND BUDGET MAFIA IN INDONESIAN PARLIAMENT
}

\section{Broker Politik dan Mafia Anggaran dalam Parlemen di Indonesia}

\author{
Moh Ilham A Hamudy ${ }^{1}$ \& Ahmad Imam M. Rais ${ }^{2}$ \\ ${ }^{1}$ Junior Researcher at Research and Development Agency \\ Ministry of Home Affairs, Republic of Indonesia \\ Jl. Kramat Raya No. 132 Jakarta Pusat \\ E-mail: ilhamhamudy80@gmail.com \\ ${ }^{2}$ Graduate Student at Melbourne University, Australia \\ Email: kangmasrais@gmail.com
}

Dikirim: 23 Juni 2014; direvisi: 5 Juli 2014; disetujui: 2 September 2014

\begin{abstract}
Budget mafia practices and brokerage phenomenon in ministries/agencies and the parliament in the country's financial dredge is very alarming. Not counted how much money is successfully robbed. The modus is varying, so it is not easy to dismantle. Because expert move, the law enforcers had trouble catching them. This article tried to describe the mode of action and often they do. The method is done by tracing the various reports in newspapers. From tracking and in-depth analysis it could be concluded that in order to minimize the action of brokers and budget mafia practices there are some necessary steps. First, fixing the finances system of political parties, reducing the dominance of parliament in budget management and election of public officials, and encourage law enforcement. Second, transparency debates the state budget in the parliament to be a key budget reforms. Third, the involvement of the community is also important to increase the transparency of the state budget discussions.
\end{abstract}

Keywords: budget mafia, broker, transparency, parliament.

\begin{abstract}
Abstrak
Praktik mafia anggaran dan fenomena broker di kementerian/lembaga dan parlemen yang mengeruk keuangan negara sangat memprihatinkan. Tidak terhitung berapa banyak uang yang berhasil dirampok. Modusnya berbeda-beda, sehingga tidak mudah untuk membongkar. Saking ahlinya, para penegak hukum mengalami kesulitan menangkap mereka. Artikel ini mencoba untuk menjelaskan modus tindakan yang kerap mereka lakukan. Metode kajian dilakukan dengan menelusuri berbagai laporan di surat kabar. Dari pelacakan dan analisis mendalam itu dapat disimpulkan bahwa untuk meminimalkan aksi broker dan praktik mafia anggaran ada beberapa langkah yang diperlukan. Pertama, memperbaiki sistem keuangan partai politik, mengurangi dominasi parlemen dalam pengelolaan anggaran dan pemilihan pejabat publik, dan mendorong penegakan hukum. Kedua, transparansi dalam perdebatan penentuan anggaran negara di parlemen menjadi kunci bagi reformasi anggaran. Ketiga, keterlibatan masyarakat juga penting untuk meningkatkan transparansi pembahasan APBN.

Kata kunci: mafia anggaran, broker, transparansi, parlemen
\end{abstract}

\section{INTRODUCTION}

Once, Wa Ode Nurhayati's who is a former member parliament of National Mandate Party (PAN), a former member of budget bodies in DPR and has been sentenced for six-years imprisoned, stated that the budget mafia which involved a broker or brokerage is evident. The statement, no doubt, worsened parliament image in public views.

Obviously, Wa Ode's statement is not a new phenomonenon. It has been becoming public awareness. According to her, the common forms that budget mafia and broker undertaken is through proposing a service to many stakeholders such as provincial governors, city mayors, regents, until business sectors (Kompas, 22/11/12). The service itself embodied through the project deals in National budget. Wa Ode guarantees that the project will be attained and implemented.
Development projects are the most common project that offered to the local leaders. It is simply because a coexistence relationship between them. In one side, local leaders need direct accesses to enable them gain development fund from national budget.

On the other hand, politician, who have an access since they managed the allocation and have full authority on that, guarantee the local leaders about the project. There is no a free lunch in this issue, absolutely. In return, a fee will be delivered to the politician as a reward. The number of fee that asked is range between 5 to 10 per cent (Republika, 6/9/12).

Obviously, the allegation of corruption, brokerage, as well as project manipulation that endorsed by Wa Ode are involved many stakeholders and remained in secrecy and underground. (Kompas, 29/9/11). It is difficult to proven those allegations as the events similar with the phenomenon of a fart or flatus. There is a (bad) smell, but we do not know who the doer is (Massardi, 2011). Luckily, we still have 
Corruption Eradication Commission (KPK) who play their role smartly, decisively, and responsively eradicating corruption.

According to KPK, generally, broker who acted as budget mafia is evident in every single ministries/ bodies/ and National parliament. Yet, many member of parliaments acted as a broker (Suara Merdeka, 14/5/2011). It is possible for a member of parliaments to become a broker as their strategic positions. Based on Parliament duties, parliament has authority in legislation and controlling. Moreover, they also have authority in managing and controlling national budget. In the event of the government proposed development budget to parliament, the broker begin to act (Rakyat Merdeka, 30/9/12).

Surely, as an insider, member of parliaments who covered themselves as a broker knows the exact amount of budget that have designed by which development in the rest of countries will be delivered. At this point, they commenced to promote their "services" either to local leaders or business sectors.

Meanwhile, the situation is suit since the other broker is brokering in ministries or state bodies. They are acting at the same time when the government delivering budget proposal in DPR. They are really sure that they can have the project, a situation that explained why they have a brave and gut to "play a scenario".

Muhammad Nazarudin's confession (who is broker), a former treasure of Democrat Party and member of budget body in DPR, about the fee on some projects, such as the development of athlete in Palembang, proved the notion of the above phenomenon.

Nazarudin said that he gained 18 per cent commission of the project, in which the money spread out to executive and DPR (Kompas, 23/1/13). The operation was undertaken as cooperation with member of DPR budget body, who asked the project or fee to ministry/bodies. In return, the proposed budget will be approved.

In line with above context, the article assessed many budget mafia operations in DPR which obviously disrupt state budget. The article aims to revealed massive phenomenon of broker in national budget and its modes which often they undertaken.

\section{RESEARCH METHODOLOGY}

The paper examined the political corruption embodied in brokerage case at House of Representative (DPR-RI). The research methodology employed in examining the case is desk study by which news in the mass media is analyzed with some theoretical framework conducted in the early part of this essay. In understanding brokerage, it cannot be separated from corruption concept in governance.

To begin with, definition of corruption should be clear. Corruption is any action that utilizes public office to gain private interest (Mikkelsen, 2013).
However, there has been broadening and deepening meaning of corruption which is not limited on "deviation from public duty" to "particular type of such deviations which breach impartiality. Thus, following this meaning, patronage clientelism, nepotism, and pork barrel is some forms of corruption.

Furthermore, in analyzing the pattern of corruption, scholars divided into two forms of corruption, namely, petty and grand corruption. Petty corruption is embodied in low level public service such as giving bribery to police or clerk in local office. On the other hand, grand corruption is a short of corruption which involved high rank politicians or public services (Karklins, 2002).

However, according above understanding, brokerage is not definitely included as another form of corruption. To fill the gap, in this paper, we argue that brokerage is another form of corruption. Brokerage could be categorized as part of grand corruption in sense of coverage amount of money and actors involved in.

Brokerage, could be categorized as patronage and clientelism corruption. It is because in achieving the goal, there should be politician, as a main actor (patron), and entrepreneur or government (client). Politician, as a power and authority holder need a foothold to utilize its power and to gain benefit. In exchange, the entrepreneur or other government actors, needs a political backup and direct access to have a first-hand information of state budget.

The politician, who should put public interest as their priority, would prioritize their client as the former will give some percentage of development budget they gain to them. As in the case of Wa Ode, which will be elaborated in the discussion part, she was looking for local government who need fund to develop their region and she assure them that she was capable to accomplish their need. In return, local governments should give her some percentage of total amount of budget for those local governments.

This pattern is more apparent in the aftermath of Soeharto, mainly after the state cut subsidies for political parties in 2005. As the result, there has been a dramatic increase of political parties' effort to fund their parties through illicit-fundraising. Their member in legislative and executive will exploit public budget to serve party's interests in conducting internal activities (Mietzner, 2007).

\section{Theoretical Review}

Theoretically, brokerage is one of small number of mechanism by which disconnected or isolated individuals (or groups) can interact economically, politically, and socially. In other word, broker simply can be defined as the mediator or middleman.

In the social life, brokerage is widely known and recognized as a casual work. Blantik (a Javanese word for animal trade), a bus, train, as well as music concert and football ticket broker are some examples 
of brokerage in daily life. Obviously, there are two dual aspects of brokerage. First, brokerage has the capacity to ease social interaction, enhance economic activity, and facilitate political development. Second, in which as contrast, brokerage often breeds exploitation, the pursuit of personal profit, corruption, and the accumulation of power; through these and other processes, brokerage can exacerbate existing in equalities (Katherine and Lynette, 2012).

There are broker who work illegally since there is a regulation that banned it. For example, a broker of train ticket in a peak season when Islamic festival days is taking a place. Yet, there is also a broker who working legally such as stock exchange broker or trader. However, most images perceived by the broker are a negative image. It might because the margin they gained from every single transaction, in which different price between retail price and consumer, is a big amount.

In economic, a broker gained a fee over it intermediary services which they performed without any interferences toward any parties who transaction. For example, insurance broker and property mere provide information about their products to consumers, while the decision whether the consumer interested in and would like to buy, is fully on consumer's side.

Meanwhile, in political realm, obviously, a broker is a part of a transaction itself. In the other word, the role of broker in power sharing, in which identical with bargain to pursue political objective in gaining a welfare society, is inevitable. However, since it refers to short-term interest, the transaction process tends to change easily and very liquid. The real broker move is as simple as they thought, what do I get today and what would I have for tomorrow. Furthermore, the transaction is getting complicated when a number of involving political actor increased and have not a solid ideological perspective yet.

Mart Bax (1976) assessed that political broker play a pivotal role as intermediary between people, businessman, or member parliament, with government or ruling parties. According to Bax, a broker has a close relationship with the ruler and will give their effort to assist any parties who need it. The way they perform the assistance is in a variety way, started from manipulation until request a help to their network in the president's men. More acquaintance they have, more powerful they perform their action in brokering. On other word, broker has a power to give a hand to other people with many ways, including a shortcuts.

In broker realm itself, they competing each other. A shortcuts or a pull-string is the way people can measure their power and connection. As a consequence, there is a levelling in their structure. The highest broker position becomes the hook for the lowest broker. It is evident that the highest broker absolutely involved a high ranks political leaders in national level, in particular who is in the cabinet or ministry.
Through the mentioned mechanism, many parties who have an interest could meet their needs to gain many projects from government such as infrastructures, school development, up to a promotion in bureaucracy. In return, people who have been assisted will give a good favour and considered the broker have power to assist or a strength to lobby (Bax, 1976: 84).

In line with Bax, Timothy Frye in Brokers and Bureaucrats (2003), revealed many reasons why in country such as Russia the role of broker is evident in economic and politic. Frye elaborated, in 1992, the time when market reformation took place in Russia was stuck, economic stabilization policy reform had not worked monthly, inflation rated was at 30-40 per cent/month and privatization toward state-owned companies had just commenced, whereas president and parliament relationship worsened, the currency trade was occupied in Russia, as a consequence, the situation boosted the broker to exist.

The broker collects their strength and then formed the Moscow Exchange, a short of exchange market which managed by lower level broker, with less than USD 30.000 funds. They trade each other to survive and eliminating bad companies. Meanwhile, broker groups have a role in commodity trades in Russia. The broker selected buyers and seller, find suit mates and if the agreement and transaction dealt, the broker gets a fee from buyers and sellers. Moreover, it is a fairness in Russia that those brokers "selling" a protection (including armed protection) for the needs, in particular when the dispute took place. The point is economic management in Russia shows how vulnerable state is in ensuring and providing a certainty for economic actors.

As a consequence, interested groups exploit and utilize the situation in which each stakeholder needs each other to gain a profit as a broker. Interesting point from Frye's analyse is that in an economic reform process, an uncertainty is part of a consequences, even for parties who have fund allocation from the ruler. Those people are who try to find a certainty with their own way. In corruption realm, what really occurred is a "sharing" principle. Clearly, if someone take some money from the flow of funds in his front side, parties who saw it and facilitated the event taking place, has to get a portion of taking funds. If it does not, the revelation of fraudulence will become a scandal in public view.

In politics and economic realm in Indonesia, sad development as Frye's argument has occurred as well. Corruption with brokerage mode had been taking place since the New Order until postreformation period. In the New Order period, brokerage embodied in the form of a concession, license, and business license for certain sectors with the main actors mostly at executive bodies and its crony.

Granting concessions, licenses and business permits are tantamount to transfer the monopoly to the 
private sector which would benefit certain circles and harmful to society at large, according hallmark of monopoly behaviour.

At the worst situation is various monopoly rights can be traded, a phenomenon that can be described and known with the term of "Ali Baba" companies. Ali refers to the indigenous-owned company whose business just to get concessions and licenses with a zero capital in the form of connections with political party leaders in the bureaucracy. Meanwhile, Baba refers to companies owned by descendants who buy concessions, licenses, and operating on the basis of concessions and licenses.

Indigenous companies such as brokers are no different than distributing various monopolies through dirty practices of corruption, collusion and nepotism $(\mathrm{KKN})$. Concession forest tenure and various import licenses, for example, have bred many conglomerate such as Barito Pacific conglomerate, Nusamba and Salim Group.

Unfortunately, the various dirty jobs of corruption practice are still going on in the reform era. Brokerage in budgeting projects in ministries/agencies and Parliament have even more spread out with the evidence of huge number of money has corrupted and stolen.

\section{RESULT AND ANALYSIS}

Budgeting scandal unfold in the House by the Commission has been dragging some figures into the prison. It is not only Nazaruddin and Wa Ode Nurhayati, as mentioned in the beginning of this paper, but also dragging political party officials. Name it, for example, Anas Urbaningrum and Andi Mallarangeng, they are still questioned for the case of the construction of a sports center Hambalang (Koran Teтpo, 19/02/13).

Later on, it also discovered other broker actor, Ahmad fathanah, in the bribery case of imported beef in the Ministry of Agriculture in which involving President the Prosperous Justice Party (PKS) Lutfi Hasan Ishaaq (Reuters, 16/05/13).

Fathanah claimed to act as a broker (Reuters, 18/05/13). He was admitted as a close friend of Lutfi since in Saudi Arabia. He insists, he is not the PKS (Justice and Prosperity Party) cadres. However, he admitted, the benefits of brokerage he undertook, occasionally donated to PKS (Jurnal Nasional, 5/18/13).

Party figures, local leaders, and members of Parliament I mentioned before often works as a broker, and/or benefiting from the actions of the broker (Rakyat Merdeka, 9/30/12). The question is, how do they get the benefit? How did the action of the broker that enable them to steal the state budget?

Typically, the broker must first prepare a draft of concept or concepts of physical construction of a project. Party broker must have had a detailed budget with the value of a decent profit. Then, the plan was carried by the broker to the executive and the legislature simultaneously or otherwise. They discussed about a mark up the price, and a division of fee for each parties, legislative, executive, and brokers (Rakyat Merdeka, 9/30/12).

Meanwhile, the project-winning company had also been determined. Mark up is usually a minimum of 40 percent and a maximum can be 100 percent dependent on the type of material to be used (Indopos, $12 / 28 / 12$ ). For example, for interior design projects, it would be marked up exceed to 100 percent. Therefore, the raw material is difficult to clearly legible. Likewise research projects, as well as social development.

Through the broker, there is an agreementeven someone has booked ealier-between the executive and the legislative for the project. Thus, the project will be included in the budget plan which is in the following process will be ratified (Seputar Indonesia, 1/10/11). At those days, the appointed company or businessmen should provide much additional services for members of the legislature and the executive.

Once approved, and then hold the tender, the tender committee have got certain instruction from member of the parliament and their 'god father' to establish a complex requirements to ensure the victory the entrepreneurs in the tender toward other competitors.

The employer also will participate with much of his company in the tender process, so it would minimize other companies' opportunity. Once the bidding process worked, the entrepreneur will be a winner through the participating company (Reuters, 08/21/11). For example, there five companies who qualifying to run the process, those five companies allegedly are the entrepreneur's company.

Therefore, behind the formal process which appropriate with existing financial and administrative regulations, the lobbyist has been taking place. The lobbying tension would be increased when decision time closer. The entrepreneur, shamelessly, would ask the broker, "How much money we should contributed to the party?" Why political parties? That's because the power brokers often pretending and covering behind their party identity.

Afterward, the winner of the auction project is decided. The brokers earn huge amounts of money. The numbers are much larger than their salary or honorarium at real work activities in the technical domain. Furthermore, the broker would move to another place to find another project. Undoubtedly, they have forgotten their previous brokerage project (Media Indonesia, 05/25/11). They are ready to look for other projects and to sell again on behalf of their party. 


\begin{tabular}{ll}
\hline \multicolumn{1}{c}{ Timeline } & \multicolumn{1}{c}{ Case Description } \\
\hline 18 January 2006 & $\begin{array}{l}\text { There is an indication of a number of members of Parliament became coordinator } \\
\text { of the distribution and disbursement of funds for the } 174 \text { districts/cities in } \\
\text { Indonesia. They ask for a fee to a number of regents/mayors if it wants to commit } \\
\text { funds. Honorary Board member of Parliament } 2 \text { Parliament later reprove. }\end{array}$ \\
\hline A member of the Budget Committee of the House of Representatives Commission \\
VIII 1999-2004 period was sentenced to 3 years imprisonment for accepting a gift \\
of Rp 250 million and Rp 1,277 billion bank draft of the Nuclear Energy \\
Regulatory Agency (Bapeten) to achieve these Bapeten budget.
\end{tabular}

Actually, trade off in political party identity is also applied in the case of beef imports bribery by which skyrocketing a businessman and broker, fathanah and PKS President, Ahmad Lutfi Hasan Ishaaq. The case is a very brightly lit confirmed it. Mary Elizabeth Liman is a suspect who is also Director of Primary Indoguna disclosed it. Elizabeth recalled it in her testimony that once she gave money to Ahmad fathanah with amount of $\mathrm{Rp} 1$ billion as donation for dawah (Islamic preaching) activities and humanitarian assistance of PKS which was held in Papua (Jawa Pos, 5/15/13).

Meanwhile, in the case of Wisma Athlete corruption, Nazaruddin's stance, actually is a broker and member of Parliament who actualize himself as entrepreneurs bidders. Nazaruddin as a broker acting as an entrepreneur at the same time, because he had 50 more companies by which widener the opportunity to win the tender. Then, once he wins, the projects are sub-contracted to other companies.

The other mode that is evidently used by most of broker who covered themselves as member of legislative is social assistance (bantuan sosial). Almost all legislators have bansos project by which provided it is for their constituency or supporting organization (Harian Andalas, 05/06/12).

It is not surprising, in every province, the number of social assistance fund is very large. Bansos process is usually carried out by non-governmental organizations who apply for aid. In fact, this is also done by executive office respectively. For each value of money that obtained assistance, 50 percent of fund is provided for members of the legislative or the executive, which is only a few of fund reached to the people.

Therefore, referring to the annual report of Indonesia Corruption Watch (ICW), 2004, 40 percent of corruption cases handled by KPK was corruption involving members of Parliament/Council, while involving executive (central/local) reached 18 percent.

In a period of five years anyway, based on annual reports ICW 2009, the Commission handled corruption cases involving members of parliament is still the highest reaching 19 percent, while involving the executives reached 18 percent (Koran Tempo, 10/04/12).

In terms of the modus, the most cases is related to abuse of the government's budget and bribery (bribery) Government agencies in order to get special treatment (privelege) as specified in the procurement process of goods and services as well as construction of public infrastructure (Reuters, 3/10/11).

Reflecting on the case in Palembang athlete development and Sports Center in Hambalang, ICW report, as well as bribery beef imports, brokerage practices apparently is well managed and organized since stage budgeting, tendering process, up to disbursement of budget.

The condition is aggravated by far-reached authority of Parliament in the government budgeting process. As a consequence, it is become the entry slit of brokerage systems in the implementation of 
government projects (Koran Tempo, 08/23/12). Unfortunately, Act 27 of 2009 about the MPR, DPR, DPD and DPRD (MD3) and Law No. 17 Year 2003 on State Finance, provide opportunities for it. MD3 in Article 107 of Law and State Finance Law Article 15 Paragraph 3 and 5 stipulated Banggar (budget body) can manage the budget from the upstream (macro budget) to downstream (micro budget) Budget. The large authority they have creates and encourage a temptation for members to corrupt and illicit practice.

At least, there are two possibility where broker can play multilevel broker in budget body (banggar) of DPR, which are budget broker for ministries/ bodies and project broker for implementing company. The slits are related with interaction between commissions in DPR with ministries/bodies as counterpart in terms of hearing session for ministries/bodies's budget which is separated from budget commission.

The worst, the hearing of the budget of ministries/agencies on related committees (budget review) is more related to general aspects without reaching impact on economic, the problem which related to the analysis limitation capacity most of members of the House (Koran Jakarta, 08/03/12). In addition, much detailed discussion opened brokerage practice implementation of government projects

\section{CONCLUSIONS}

To sum up, the budget mafia crimes and acts of the broker must be mitigated with systematic efforts. The efforts are through fixing the financial system of political parties, reducing dominance of parliament in budget management and selection of public officials, and encourage law enforcement.

Transparency is inevitable as a budgetary reform. It is embodied since in the beginning of budget process in government side, hearing session in parliament up to the implementation and evaluation. Without transparency in the whole process of budget, any improvement would be redundant. It is need a political will of the each party who involved in budget process to create a transparent system and accessible budget for public in order to minimize the practice of collusion and corruption.

The reason for this is because the hearing session of the budget is always a closed session, a situation that can be used as an opportunity for the budget mafia. The implementing projects tend to political interests of politicians in Parliament and government officials.

Transparency since the beginning of the budget discussion in the House of Representatives as well as the involvement of the Commission apparently was not enough to combat the rampant acts of brokers in the House. Budgeting mechanism needs to be changed with the public is actively involved in the hearing.

The involvement of the community is also in order to improve the transparency of the budget hearing. Later on, the House should publish to the public the details of the government's budget. In the following process, the public was also has opportunity to give a feedback on the draft budget.

Lastly, in an extreme case is to dissolve the budget body. The argument is, first, the corruption of member of budget body, who are also often act as brokers, have created an unhealthy democracy. Second, the dissolution Banggar related to the principle of separation of state power in a democratic system . If budget body is abolished, the authority to manage micro budget is handed over to the government

In the future, it would be better if the budget function of parliament is interpreted only in the determination of the macro budget . Parliament is only involved in designing the grand design of the management of the state budget. Executor of the draft was handed over entirely to the government. When the government failed to realize the micro- budget , the House has room to question the concept of government economic policy .

\section{REFERENCES}

\section{Book}

Bax, Mart. 1976. Harpstring and Confessions: Machine Style Politics in the Irish Republic. Amsterdam: Van Gorcum

Frye, Timothy M. 2000. Broker and Bureaucrats: Building Market Institutions in Russia. New York: University of Michigan Press

Kunio, Yoshihara. 1990. Kapitalisme Semu Asia Tenggara. Jakarta: LP3ES

Pielke Jr, Roger A. 2007. The Honest Broker: Making Sense of Science in Policy and Politics. New York: Cambridge University Press

Robison, Richard. 1986. Indonesia: the Rise of Capital. Canberra: Allen and Unwin Pty Ltd

Wedel, Janine R. 2009. Shadow Elite: How the World's New Power Brokers Undermine Democracy, Government, and the Free Market. New York: Basic Books

Wright, Jeffrey P. 1990. What is Business Worth: for Buyers, Sellers, and Brokers. New York: Rourke Publishing

Journal

Karklins, Rasma. 2002. Typology of Post-Communist Corruption. Problems of Post-Communism. Vol 49 No 4 July/August

Mikkelsen, Kim Sass. 2013. In Murky Waters: A Disentangling of Corruption and Related Concepts. Crime Law Soc Change.

Mietzner, Marcus. 2007. Party Financing in PostSoeharto Indonesia: Between State Subsidies and Political Corruption. Contemporary Southeast Asia Vol. 29 No. 2

Stovel, Katherine and Lynette, Shaw. Brokerage. The Annual Review of Sociology. Soc.annualreviews. org 2011 


\section{Newspaper}

Kamaruddin Yakin Nazaruddin Bos Sang Broker Suap di Kemenegpora (Rakyat Merdeka, 2 Mei 2011)

ICW: Banyak Broker Seperti Rosa di Gedung DPR (Suara Merdeka, 14 Mei 2011)

Politisi PKS Beber 4 Modus Calo Anggaran (Republika, 19 Mei 2011)

Calo Anggaran Masih Gentayangan di Senayan (Media Indonesia, 25 Mei 2011)

Politik Anggaran Sudah Tidak Sehat (Koran Jakarta, 3 Agustus 2011)

Nazaruddin Sang Mujahidin (Artikel Adhie Massardi dimuat Rakyat Merdeka, 11 Agustus 2011)

Enam Celah Mafia Anggaran di DPR (Kompas, 21 Agustus 2011)

KPK Harus Perketat Pengawasan Tender (Republika, 28 September 2011)

Permainan di Badan Anggaran Tertutup (Kompas, 29 September 2011)

Korban: Proyek Tidak Jalan, Fee Lenyap (Rakyat Merdeka, 30 September 2011)

Sepuluh Anggota DPR Jadi Calo Anggaran? (Rakyat Merdeka, 30 September 2011)

Pos P2MA: Anggota DPR Simpul Pertama Praktik Mafia Anggaran (Rakyat Merdeka, 30 September 2011)

Ada Sistem Ijon di Banggar DPR (Seputar Indonesia, 1 Oktober 2011)

Modus Pengerukan Anggaran (Kompas, 3 Oktober 2011)

KPK Didesak Usut Calo Anggaran (Kompas, 5 Oktober 2011)

Sekali Tender, Broker Untung Miliyaran Rupiah (Jawa Pos, 4 Februari 2012)

Korupsi Pengadaan Paling Banyak Ditangani KPK (Koran Tempo, 10 April 2012)

Penyimpangan Bansos Harus Dituntaskan (Harian Andalas, 5 Juni 2012)

Wa Ode: Saya Korban Mafia Anggaran DPR (Kompas, 19 Juni 2012)

Pembahasan Anggaran di DPR Jangan Terlalu Terperinci (Koran Tempo, 23 Agustus 2012)

Angie Minta Jatah 5 Persen Proyek Kemendiknas (Republika, 6 September 2012)

Menkeu Minta Kepala Daerah Jangan Percaya Broker Anggaran (Jawa Pos, 9 Oktober 2012)

KPK Tetapkan Haris Surahman Tersangka Baru DPID (Kompas, 22 November 2012)

Praktik Mark Up Proyek Hambalang Sengaja Dilakukan (Indopos, 28 Desember 2012)

MA Perberat Vonis Nazaruddin Jadi 7 Tahun (Kompas, 23 Januari 2013)

Menteri Agus Akan Buka-bukaan Kasus Hambalang (Koran Tempo, 19 Februari 2013)

Para Broker Kapling Kekuasaan di Senayan (Republika, 1 Mei 2013)

Maria: Duit Rp 1 Miliar Untuk Safari Dakwah PKS (Jawa Pos, 15 Mei 2013)

Lobi Fathanah Seizin Luthfi (Kompas, 16 Mei 2013)

Fathanah: Saya Calo Proyek (Republika, 18 Mei 2013)

Kasus Impor Daging Sapi Luthfi-Fathanah Atur Skenario (Jurnal Nasional, 18 Mei 2013) 
